\title{
IL-6-174 G/C and ApoE Gene Polymorphisms in Alzheimer's and Vascular Dementia Patients Attending the Cognitive Disorder Clinic of the All India Institute of Medical Sciences, New Delhi
}

\author{
Nasim Mansoori ${ }^{\text {a }}$ Manjari Tripathi ${ }^{\mathrm{b}}$ Rizwan Alam ${ }^{\mathrm{a}}$ e Kalpana Luthra ${ }^{\mathrm{c}}$ \\ Lakshmy Ramakrishnan ${ }^{d}$ Shama Parveen ${ }^{\text {e Asok K. Mukhopadhyaya }}{ }^{a}$ \\ Departments of a Laboratory Medicine, ${ }^{\mathrm{b}}$ Neurology, ${ }^{\mathrm{c} B i o c h e m i s t r y}$ and ${ }^{\mathrm{d}}$ Cardiac Biochemistry, All India \\ Institute of Medical Sciences, and ${ }^{\mathrm{e} C e n t r e ~ f o r ~ I n t e r d i s c i p l i n a r y ~ R e s e a r c h ~ i n ~ B a s i c ~ S c i e n c e s, ~ J a m i a ~ M i l l i a ~ I s l a m i a, ~}$ \\ New Delhi, India
}

\author{
Key Words \\ Alzheimer's disease - Apolipoprotein E - Dementia • \\ Interleukin-6 $\cdot$ Neurodegenerative disease • \\ Polymorphism • Vascular dementia
}

\begin{abstract}
Background: Remarkable improvement in the life expectancy of the Indian population is expected to commensurate with the increase in number of dementia cases. Among various types of dementia, Alzheimer's disease (AD) and vascular dementia ( $\mathrm{VaD}$ ) are common and widely studied. We evaluated the role of apolipoprotein $E(A p o E)$ and interleukin- 6 (IL-6)-174 G/C gene polymorphism along with serum IL-6 levels in AD and VaD patients. Methods: The polymorphisms in ApoE and IL-6-174 G/C genes were assessed using RFLP. Serum IL- 6 level was measured by ELISA. Results: The allele $\varepsilon 4$ of the ApoE gene was found to be associated with $A D$ and VaD patients $(p<0.05)$. No association of IL- $6-174 \mathrm{G} / \mathrm{C}$ polymorphism was observed in AD patients, while the IL-6-174 C allele increased the odds of having $\mathrm{VaD}$ twofold. Regression analysis to assess possible interaction between ApoE and the IL-6-174 G/C genes revealed that presence of both the $\varepsilon 4$ and $C$ alleles increased the odds of having AD 13.75-fold and VaD 14.7-fold. Serum IL-6 levels did not correlate with either
\end{abstract}

presence or severity of disease among AD or VaD patients. Conclusion: The ApoE $\varepsilon 4$ allele is an important genetic marker for $A D$ and $\mathrm{VaD}$. Presence of both ApoE $\varepsilon 4$ and IL-6 C genes increases the OR of having $A D$ and $\mathrm{VaD}$ markedly.

Copyright $\odot 2011$ S. Karger AG, Basel

\section{Introduction}

Dementia is defined as a decline in mental abilities and cognitive functions which eventually impairs the ability of an individual to carry out everyday activities. The 2 most common types of dementia are Alzheimer's disease (AD) and vascular dementia (VaD).

As per the 2005 estimate of the World Health Organization (WHO), nearly $0.379 \%$ of the world's population had dementia and this will further increase to $0.556 \%$ by the year 2030. Well-conducted studies in India [1] and China [2] suggest similar prevalence rates for dementia as seen in the developed countries. A recent study conducted by Kalaria et al. [3] reported that the percentage prevalence of $\mathrm{AD}$ and $\mathrm{VaD}$ among adults $>65$ years of age in

Nasim Mansoori and Rizwan Alam contributed equally to this work.

\section{KARGER}

Fax +4161306 1234

E-Mail karger@karger.ch

www.karger.com
(C) $2011 \mathrm{~S}$. Karger AG, Basel

$1420-8008 / 10 / 0306-0461 \$ 26.00 / 0$

Accessible online at:

www.karger.com/dem
Prof. Dr. A.K. Mukhopadhyay

Department of Laboratory Medicine, PO Box No. 4938

All India Institute of Medical Sciences, Ansari Nagar

New Delhi 110029 (India)

Tel. +91 112649 4407, Fax +91 112658 8641, E-Mail mukhoak53@yahoo.com 
India is nearly 1.3 and $1.1 \%$, respectively. Considering India's increasing life expectancy and population of nearly 70 million elderly persons, the number of dementia cases is expected to go up, and as a result, the demands for health care of demented people will rise remarkably in this century [4].

$\mathrm{AD}$ is characterized by progressive cognitive deterioration with declining daily living activities and neuropsychiatry symptoms. In $\mathrm{AD}$, the pathological process consists principally of neuronal loss or atrophy, mild inflammatory response with deposition of amyloid, and formation of neurofibrillary tangles and $\beta$-amyloid plaques [5]. This neurodegenerative disease has a multifactorial etiology involving complex interactions of both genetic and environmental factors. $\mathrm{VaD}$ results from heterogeneous brain lesions caused by ischemia, hypoperfusion or hemorrhage of cerebral tissue. The pathophysiology of $\mathrm{VaD}$ is complex and involves a number of mechanisms, including reduction of cerebral blood flow, alteration of oxygen metabolism and inflammatory mechanisms.

Genetic factors have been widely proven to be associated with both $\mathrm{AD}$ and $\mathrm{VaD}$. In sporadic $\mathrm{AD}$, many candidate genes are involved in the metabolism of $\beta$-amyloid $[\alpha-2$-macroglobulin, cystin $\mathrm{C}$, low-density lipoproteinrelated protein 1, apolipoprotein $\mathrm{E}$ (ApoE), cathepsin $\mathrm{D}$, etc.] or protein which mediates the $\mathrm{AD}$-related immune system reaction like interleukin (IL)-1 $\alpha$ and IL-6 [6]. ApoE has been widely studied and is a well-established risk factor for $\mathrm{AD}$. Out of 3 alleles of ApoE, $\varepsilon 4$ allele has been associated with an increased risk of AD [7-11]. ApoE $\varepsilon 4$-targeted replacement in mice demonstrated a proinflammatory phenotype including increased iNOS mRNA synthesis and NO production, and higher proinflammatory cytokine production (TNF- $\alpha$, IL-6, IL-12p40) in glial cell culture in comparison to the ApoE $\varepsilon 3$-targeted replacement mice [12]. Several studies in the past have been conducted to find an association of the IL-6-174 G/C polymorphism with $\mathrm{AD}$, but the results have been inconsistent. Studies conducted across varying geographical areas have yielded different results: some have shown a positive association [13-18], while others have found none [19-26]. Additionally, serum IL-6 levels have also been reported to be increased in some studies [13, 14], while in others no significant differences were observed in comparison to the healthy controls $[27,28]$.

India has a vast prevalence of the disease as mentioned earlier, and this fact has gone almost unnoticed. The major objective of the current study was to determine whether ApoE and/or IL-6-174 G/C polymorphism have any association with $\mathrm{AD}$ and $\mathrm{VaD}$, and also whether there is any association of serum levels of IL- 6 with polymorphism of IL-6-174 G/C genes (rs 1800795) in the Indian population.

\section{Patients and Methods}

\section{Patients}

All patients coming to the cognitive disorder clinic at All India Institute of Medical Sciences (AIIMS), New Delhi, during November 2007 to February 2010 were screened for dementia. The patients were identified as having dementia by DSM-IV, MiniMental State Examination (MMSE score $\leq 24$ out of 30) and detailed neurological examination [29]. Further, NINCDS-ADRDA and NINDS-AIREN were used for classification of AD and VaD. A total of 74 patients with $\mathrm{AD}$ and 46 with $\mathrm{VaD}$ were recruited for the present study. The age group of the patients recruited was $\geq 50$ years. A detailed pedigree chart was drawn for all patients and none was found to have family history. All patients having any reversible cause of dementia like vitamin $\mathrm{B}_{12}$ deficiency, hypothyroidism or neuro-infections causing dementia (neurosyphilis, HIV, tuberculosis) and rapidly progressive dementia (dementia evolving and progressing from stage I to stage III in $\leq 6$ months) were excluded from the current study. Magnetic resonance imaging (MRI) of the brain was done in all patients to confirm the diagnosis.

\section{Healthy Controls}

A total of 113 healthy controls (of comparable age and gender matched \pm 3 years) were recruited and their MMSE scores were determined. All the healthy controls that had MMSE scores of $\leq 24$ or a history of disease (cardiovascular, stroke, diabetes, AIDS or tuberculosis) were excluded. This study protocol was approved by the ethics committee of AIIMS. Consent for the study was obtained from all the enrolled subjects.

\section{Sample Collection}

Approximately $6 \mathrm{ml}$ of blood was collected from fasting subjects in the supine position and was drawn by puncture of the antecubital vein. The drawn blood was equally distributed in plain and EDTA vials for biochemical and genetic studies, respectively.

\section{DNA Extraction}

Genomic DNA was extracted from the EDTA-treated blood by the salting out method [30]. The yield of the extracted DNA was then measured at $260 \mathrm{~nm}$ using a spectrophotometer and the purity was calculated using the $260 / 280-\mathrm{nm}$ ratio. All DNA samples were stored at $-20^{\circ} \mathrm{C}$ until further analysis.

\section{ApoE Genotyping}

Amplification of the ApoE gene-containing region of the DNA was amplified in a Mastercycler Ep Gradient Thermocycler (Eppendorf AG, Hamburg, Germany) using 100-ng of the genomic DNA. The ApoE gene was amplified using previously published primers [31]. Briefly, $25 \mu \mathrm{l}$ of PCR product was generated using $100 \mathrm{ng}$ genomic DNA, $10 \times$ reaction buffer, $0.2 \mathrm{~mm}$ deoxynucleotide triphosphates, $15 \mathrm{mM} \mathrm{MgCl}_{2}, 20$ pmol of each primer and 1.5 units of Taq DNA polymerase (New England Biolabs, USA). The
Mansoori/Tripathi/Alam/Luthra/ Ramakrishnan/Parveen/Mukhopadhyay 
The PCR profile involved initial denaturation at $94^{\circ} \mathrm{C}$ for $5 \mathrm{~min}$, followed by 35 cycles at $94^{\circ} \mathrm{C}$ for $30 \mathrm{~s}, 65^{\circ} \mathrm{C}$ for $30 \mathrm{~s}$ and $72^{\circ} \mathrm{C}$ for $30 \mathrm{~s}$, with a final extension at $72^{\circ} \mathrm{C}$ for $7 \mathrm{~min}$. The amplified product was electrophoresed on a $2 \%$ agarose gel. Further genotyping was done following digestion of $10 \mu \mathrm{l}$ of the amplified product using 5 units of HhaI restriction enzyme (New England Biolabs) and incubated at $37^{\circ} \mathrm{C}$ for $5 \mathrm{~h}$. The digested product was further separated on an $8 \%$ polyacrylamide gel and visualized by silver staining.

\section{IL-6-174 G/C Genotyping}

For amplification of the IL-6-174 G/C (rs 1800795), the genecontaining region of the DNA was amplified using previously published primers [32]. Briefly, $25 \mu$ l of PCR product was generated using $100 \mathrm{ng}$ of genomic DNA, $10 \times$ reaction buffer, $0.2 \mathrm{mM}$ of deoxynucleotide triphosphates, 20 pmol of each primer and 1.5 units of Taq DNA polymerase. The PCR profile involved initial denaturation at $95^{\circ} \mathrm{C}$ for $10 \mathrm{~min}$, followed by 35 cycles at $94^{\circ} \mathrm{C}$ for $1 \mathrm{~min}, 55^{\circ} \mathrm{C}$ for $1 \mathrm{~min}$ and $72^{\circ} \mathrm{C}$ for $1 \mathrm{~min}$, with a final extension at $72^{\circ} \mathrm{C}$ for $10 \mathrm{~min}$. The amplified product was electrophoresed on a $2 \%$ agarose gel. Further genotyping was done following digestion of $10 \mu \mathrm{l}$ of the amplified product using 2 units of SfaNI restriction enzyme and incubation at $37^{\circ} \mathrm{C}$ for $5 \mathrm{~h}$. The digested product was further separated on a $2.5 \%$ agarose gel and visualized under a transilluminator.

Estimation of IL-6

The levels of IL- 6 cytokine in serum of all patients and controls were determined using a commercially available ELISA kit (Ready-SET-Go! Human Interleukin-6, eBioscience, USA) as per the manufacturer's protocol. The intra- and interassay coefficients of variation were $2.8-5.4$ and $4.1-7.9 \%$, respectively.

\section{Statistical Analysis}

All statistical analysis was done using SPSS, version 17.0. The descriptive analysis, mainly means and SD for age, sex, onset of disease and other clinical symptoms, was calculated for all patients and controls. Differences in genotype and allelic distribution among the diseased and healthy controls were determined using a $\chi^{2}$ test, with the OR and 95\% CI calculated subsequently. Multinomial logistic regression was also done to examine the interaction between ApoE and the IL-6-174 G/C alleles.

\section{Results}

In this case control study, a total of 233 subjects, which included $74 \mathrm{AD}, 46 \mathrm{VaD}$ and 113 controls, were studied for polymorphism in ApoE and the IL-6-174 G/C genes. Serum IL- 6 was also measured in all subjects.

\section{Demographic and Clinical Profile of the Subjects}

Table 1 shows the demographic and clinical profile of the control and the patients with $\mathrm{AD}$ and $\mathrm{VaD}$. There was no significant difference in the mean age group of $\mathrm{AD}$ $(66.4 \pm 9.2)$ or $\mathrm{VaD}(66.1 \pm 8.8)$ in comparison to the control subjects $(64.0 \pm 8.4)$. However, there was a rela-
Table 1. Demographic and clinical characteristics of the 3 study groups

\begin{tabular}{|c|c|c|c|c|}
\hline & $\begin{array}{l}\mathrm{AD} \\
(\mathrm{n}=74)\end{array}$ & $\begin{array}{l}\mathrm{VaD} \\
(\mathrm{n}=46)\end{array}$ & $\begin{array}{l}\text { Healthy } \\
\text { controls } \\
(\mathrm{n}=113)\end{array}$ & $\mathrm{p}$ \\
\hline Age $^{\mathrm{a}}$ (in years) & $66.4 \pm 9.2$ & $66.1 \pm 8.8$ & $64.0 \pm 8.4$ & $>0.05^{b, c}$ \\
\hline Onset of disease ${ }^{a}$ & & & & \\
\hline (in years) & $63.2 \pm 9.3$ & $63.6 \pm 8.2$ & - & $>0.05^{\mathrm{d}}$ \\
\hline \multicolumn{5}{|l|}{ Sex } \\
\hline Male & 50 & 34 & 72 & $>0.05^{\mathrm{b}, \mathrm{c}}$ \\
\hline Female & 24 & 12 & 41 & \\
\hline MMSE & $17.2 \pm 4.6$ & $17.4 \pm 4.7$ & - & $>0.05^{\mathrm{d}}$ \\
\hline BDR & $13.6 \pm 4.2$ & $13.4 \pm 4.2$ & - & $>0.05^{\mathrm{d}}$ \\
\hline IADL & $19.4 \pm 7.4$ & $16.7 \pm 6.8$ & - & $0.041^{\mathrm{d}}$ \\
\hline
\end{tabular}

$\mathrm{BDR}=$ Blessed dementia rating; $\mathrm{IADL}=$ incremental activities of daily living.

${ }^{\text {a }}$ Values are represented as means $\pm \mathrm{SD}$.

b AD vs. healthy controls.

${ }^{c} \mathrm{VaD}$ vs. healthy controls.

d AD vs. VaD.

tively low percentage of females in the $\mathrm{AD}(32.4 \%)$ and $\mathrm{VaD}(26.1 \%)$ groups, which was not significantly different from the control group. One interesting feature is that out of $74 \mathrm{AD}$ cases, 17 patients (11 male and 6 female) were below 60 years of age.

The means with SD of MMSE, BDR and IADL for AD and $\mathrm{VaD}$ patients were $17.2 \pm 4.6$ and $17.4 \pm$ 4.7, $13.6 \pm$ 4.2 and $13.4 \pm 4.2,19.4 \pm 7.4$ and $16.7 \pm 6.8$, respectively (table 1). Significant differences among the mean incremental activities of daily living levels were observed within the $\mathrm{AD}$ and $\mathrm{VaD}$ groups $(\mathrm{p}=0.041)$, while the levels of MMSE and the Blessed dementia rating were not significantly different.

\section{Allele Distribution and Genotyping of ApoE Genes in $A D$ and $V a D$}

Table 2 shows the ApoE allele distribution and genotyping found in $\mathrm{AD}$ and $\mathrm{VaD}$ patients as compared to controls. The frequency of ApoE alleles $\varepsilon 2, \varepsilon 3$, and $\varepsilon 4$ were examined in 233 subjects. Allele $\varepsilon 2$ was absent in $\mathrm{AD}$ patients and was present in only 1 case of $\mathrm{VaD}$ patients as compared to 7 out of 113 control subjects. Allele $\varepsilon 3$ was present in $90.3 \%$ of the controls, $73 \%$ of the AD cases and $81.5 \%$ of the $\mathrm{VaD}$ cases. The frequency of allele $\varepsilon 4$ was found to be significantly high in the $\mathrm{AD}(27 \%)$ and $\mathrm{VaD}(17.4 \%)$ cases as compared to control subjects (6.6\%). Compared to the $\varepsilon 3$ allele, the $\varepsilon 4$ allele was more frequent 
Table 2. Allele and genotype distribution of the ApoE gene among diseased and healthy control groups

\begin{tabular}{|c|c|c|c|c|}
\hline & $\begin{array}{l}\mathrm{AD} \\
(\mathrm{n}=74)\end{array}$ & $\begin{array}{l}\mathrm{VaD} \\
(\mathrm{n}=46)\end{array}$ & $\begin{array}{l}\text { Healthy } \\
\text { controls } \\
(\mathrm{n}=113)\end{array}$ & $\mathrm{p}$ \\
\hline \multicolumn{5}{|l|}{ Alleles } \\
\hline$\varepsilon 2$ & - & $1.1(1)$ & $3.1(7)$ & $\begin{aligned} & 0.045^{\mathrm{a}} \\
> & 0.05^{\mathrm{b}}\end{aligned}$ \\
\hline$\varepsilon 3$ & $73.0(108)$ & $81.5(75)$ & $90.3(204)$ & $\begin{array}{r}<0.001^{\mathrm{a}} \\
0.031^{\mathrm{b}}\end{array}$ \\
\hline$\varepsilon 4$ & $27.0(40)$ & $17.4(16)$ & $6.6(15)$ & $\begin{array}{l}<0.001^{\mathrm{a}} \\
<0.003^{\mathrm{b}}\end{array}$ \\
\hline \multicolumn{5}{|c|}{ Genotypes } \\
\hline$\varepsilon 2 \varepsilon 2$ & - & - & - & - \\
\hline$\varepsilon 2 \varepsilon 3$ & - & $2.2(1)$ & $5.3(6)$ & $>0.05^{\mathrm{a}, \mathrm{b}}$ \\
\hline$\varepsilon 2 \varepsilon 4$ & - & - & $0.9(1)$ & $>0.05^{\mathrm{a}, \mathrm{b}}$ \\
\hline$\varepsilon 3 \varepsilon 3$ & $54.1(40)$ & $67.4(31)$ & $81.4(92)$ & $\begin{array}{l}<0.001^{\mathrm{a}} \\
>0.05^{\mathrm{b}}\end{array}$ \\
\hline$\varepsilon 3 \varepsilon 4$ & $37.8(28)$ & $26.1(12)$ & $12.4(14)$ & $\begin{array}{r}<0.001^{\mathrm{a}} \\
0.034^{\mathrm{b}}\end{array}$ \\
\hline$\varepsilon 4 \varepsilon 4$ & $8.1(6)$ & $4.3(2)$ & - & $\begin{aligned} & 0.003^{\mathrm{a}} \\
&>0.05^{\mathrm{b}}\end{aligned}$ \\
\hline
\end{tabular}

Figures in parentheses represent numbers.

a AD vs. healthy controls.

${ }^{\mathrm{b}} \mathrm{VaD}$ vs. healthy controls.
Table 3. Allele and genotype distribution of IL-6-174 G/C gene among diseased and healthy control groups

\begin{tabular}{|c|c|c|c|c|}
\hline & $\begin{array}{l}\mathrm{AD} \\
(\mathrm{n}=74)\end{array}$ & $\begin{array}{l}\mathrm{VaD} \\
(\mathrm{n}=46)\end{array}$ & $\begin{array}{l}\text { Healthy } \\
\text { controls } \\
(\mathrm{n}=113)\end{array}$ & $\mathrm{p}$ \\
\hline \multicolumn{5}{|l|}{ Alleles } \\
\hline G & $83.8(124)$ & $73.9(68)$ & $85.0(192)$ & \multirow[t]{2}{*}{$\begin{array}{r}>0.05^{\mathrm{a}} \\
\quad 0.021^{\mathrm{b}}\end{array}$} \\
\hline $\mathrm{C}$ & $16.2(24)$ & $26.1(24)$ & $15.0(34)$ & \\
\hline \multicolumn{5}{|c|}{ Genotypes } \\
\hline $\mathrm{GG}$ & $68.9(51)$ & $54.4(25)$ & $72.6(82)$ & $\begin{array}{l}>0.05^{\mathrm{a}} \\
0.026^{\mathrm{b}}\end{array}$ \\
\hline GC & $29.7(22)$ & $39.1(18)$ & $24.8(28)$ & $>0.05^{\mathrm{a}, \mathrm{b}}$ \\
\hline $\mathrm{CC}$ & $1.4(1)$ & $6.5(3)$ & $2.6(3)$ & $>0.05^{\mathrm{a}, \mathrm{b}}$ \\
\hline \multicolumn{5}{|c|}{$\begin{array}{l}\text { Figures in parentheses represent numbers. } \\
\text { a AD vs. healthy controls. } \\
\text { b VaD vs. healthy controls. }\end{array}$} \\
\hline
\end{tabular}

Allele Frequency and Genotype of IL-6-174 G/C Genes in $A D$ and $V a D$

From the data as shown in table 3 , it is clear that there was no significant difference in distribution of allele frequency $\mathrm{G}$ in $\mathrm{AD}(83.8 \%)$ and $\mathrm{VaD}$ cases $(73.9 \%)$ in contrast to the control subjects (85\%).

However, there was a significant difference of frequency of $\mathrm{C}$ allele in $\mathrm{VaD}$ cases (26.1\%) as compared to control subjects $(15 \%)$, while no such difference was found in $\mathrm{AD}$ cases (16.2\%). Compared to the $\mathrm{G}$ allele, the $\mathrm{C}$ allele was more frequent among VaD cases $(\mathrm{p}=0.021)$ as compared to the controls. The absence of the $\mathrm{G}$ allele increased the odds of having VaD 2.2-fold (95\% CI: 1.034.82).

Of the 3 genotypes GG, GC and CC, the last one (CC) was less frequent in controls (2.6\%) as compared to $\mathrm{AD}$ (1.4\%) and $\mathrm{VaD}(6.5 \%)$, while the first one $(\mathrm{GG})$ was found more frequently. While no correlation of genotype GG was found in the AD patients, there was a statistically significant correlation $(\mathrm{p}=0.026)$ between the controls and $\mathrm{VaD}$ patients.

\section{Probability of Interaction of ApoE and IL-6-174 G/C}

Gene in Causation of $A D$ and $V a D$

To assess the interplay of ApoE and the IL-6-174 G/C genes in causation of $\mathrm{AD}$ and $\mathrm{VaD}$, multinomial logistic regression analysis was done. In absence of the $\varepsilon 4$ allele, the IL-6 C allele alone did not have any significant causal relationship with either $\mathrm{AD}(\mathrm{p}=0.93)$ or $\operatorname{VaD}$ cases $(\mathrm{p}=$ 
Table 4. Regression analysis to show OR for $\mathrm{AD}$ and $\mathrm{VaD}$ in interaction between ApoE and IL-6-174 G/C alleles

\begin{tabular}{|c|c|c|c|c|c|c|}
\hline ApoE $\varepsilon 4$ & IL-6 C & $\begin{array}{l}\text { Healthy } \\
\text { controls }\end{array}$ & $\mathrm{AD}$ & $\mathrm{VaD}$ & $\mathrm{p}$ & OR $(95 \% \mathrm{CI})$ \\
\hline - & - & 70 & 28 & 19 & & 1 (reference) \\
\hline - & + & 29 & 12 & 13 & $\begin{array}{l}0.93^{\mathrm{a}} \\
0.23^{\mathrm{b}}\end{array}$ & $\begin{array}{l}1.03(0.46-2.30)^{\mathrm{c}} \\
1.65(0.72-3.78)^{\mathrm{d}}\end{array}$ \\
\hline+ & - & 12 & 23 & 6 & $\begin{array}{c}<0.001^{\mathrm{a}} \\
0.28^{\mathrm{b}}\end{array}$ & $\begin{array}{l}4.79(2.10-10.92)^{\mathrm{c}} \\
1.84(0.61-5.55)^{\mathrm{d}}\end{array}$ \\
\hline+ & + & 2 & 11 & 8 & $\begin{array}{l}0.001^{\mathrm{a}} \\
0.001^{\mathrm{b}}\end{array}$ & $\begin{array}{l}13.75(2.86-66.03)^{\mathrm{c}} \\
14.74(2.89-75.24)^{\mathrm{d}}\end{array}$ \\
\hline
\end{tabular}

$+/-=$ Presence/absence

a AD vs. healthy controls. ${ }^{\mathrm{b}} \mathrm{VaD}$ vs. healthy controls. ${ }^{\mathrm{c}} \mathrm{AD}$ and healthy controls. ${ }^{\mathrm{d}} \mathrm{VaD}$ and healthy controls.
0.23 ). The association with AD cases was significant ( $\mathrm{p}<$ 0.001 ) in the presence of the $\varepsilon 4$ allele and in absence of the IL- $6 \mathrm{C}$ allele, while for $\mathrm{VaD}$ cases such an association was statistically insignificant. The presence of both the ApoE $\varepsilon 4$ and IL- $6 \mathrm{C}$ alleles had a positive modifier effect, increasing the OR of having AD 13.75-fold and 14.74-fold for $\mathrm{VaD}$.

\section{Serum Levels of IL-6}

The serum IL- 6 levels determined in all 3 groups $(\mathrm{AD}, \mathrm{VaD}$, controls) are shown in figure 1 . The median (range) of IL-6 ( $\mathrm{pg} / \mathrm{ml})$ levels among the healthy controls, AD and $\mathrm{VaD}$ groups were 2.91 (0-24.85), 3.82 (0$32.56)$ and 4.49 (0-23.8), respectively (fig. 1). The Kruskal-Wallis test revealed no significant differences in the IL-6 levels among the 3 groups ( $p>0.05$ ). No association between serum IL- 6 level and IL- 6 gene polymorphisms was observed. In $17 \mathrm{AD}$ patients who were below 60 years of age, the median of serum IL-6 level was 3.61 (0-6.78) as compared to 57 patients above 60 years of age whose median value was $3.92(0-32.56)$. Therefore, the present study does not show any statistically significant rise of IL- 6 with advancement of age. Twenty-four samples (12 within the healthy control group and 6 each within the $\mathrm{AD}$ and $\mathrm{VaD}$ groups) did not have detectable IL-6 levels.

\section{Discussion}

The present study has shed light on epidemiological and etiopathological aspects of 2 predominant dementias, $\mathrm{AD}$ and $\mathrm{VaD}$, diagnosed clinically and confirmed with the help of MRI at AIIMS.

IL-6 and ApoE Gene Polymorphism in $\mathrm{AD}$ and $\mathrm{VaD}$ Patients

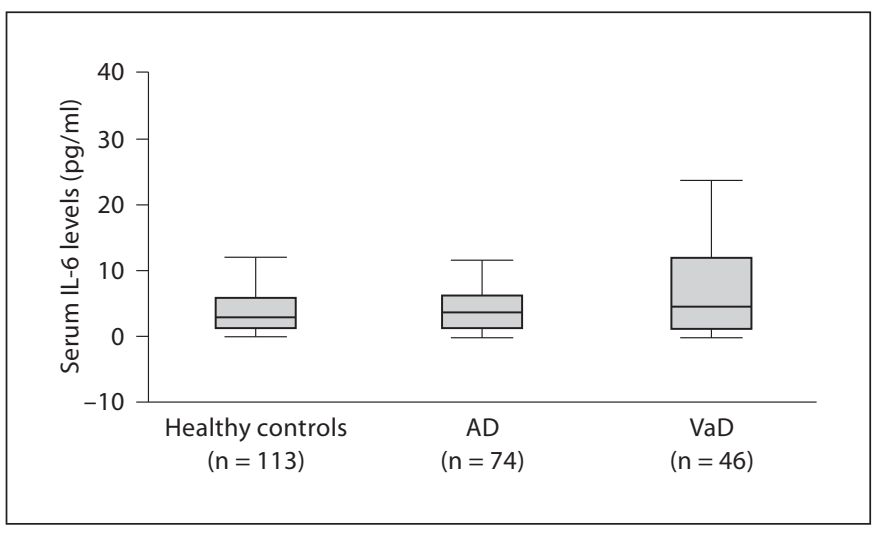

Fig.1. Box plot showing serum IL-6 levels of the 3 study groups.

Concerning the epidemiological aspect, a higher $\varepsilon 4$ allele frequency (27\%) was observed in the Alzheimer's group in comparison to the healthy controls $(6.6 \%)$. The percentage prevalence of the $\varepsilon 4$ allele among the diseased populations worldwide, however, is not consistent. Studies from Norway and Spain $[7,8]$ have reported a higher frequency of the $\varepsilon 4$ allele, while relatively lower percentages have been reported from Hungary and Iran $[33,34]$. Observations similar to our study have been reported in the past from Italy, Israel and China [9-11]. A recently conducted study involving neurodegenerative cases of dementia reported low frequency of the $\varepsilon 4$ allele (15\%) in the Indian population [35]. The present study has shown that the presence of the $\varepsilon 4$ allele increases the risk of $\mathrm{AD}$ nearly sixfold, which clearly portrays causal linkage of the $\varepsilon 4$ allele of the ApoE gene with AD. Such an observation has been well established in earlier reported studies

Dement Geriatr Cogn Disord 2010;30:461-468 
as well. Among the genotypes, $\varepsilon 3 \varepsilon 4$ was observed to be widely prevalent among the diseased groups in comparison to the healthy controls $(\mathrm{p}<0.001)$, which is in accordance with earlier studies [36].

On the other hand, in the cases of $\mathrm{VaD}$, the association of the $\varepsilon 4$ allele is debatable. In the literature, one can find both an association [8-11] and no association [35-37] with ApoE polymorphism. In the present study, the frequency of the $\varepsilon 4$ allele was significantly higher in cases of $\mathrm{VaD}$ patients (17.4\%) in comparison to the control group ( $\mathrm{p}=0.003)$. The percentage prevalence of the $\varepsilon 4$ allele was similar to studies from Hungary and China [11, 33]; however, one of the previous studies from our institute reported a relatively higher frequency of the $\varepsilon 4$ allele in $\mathrm{VaD}$ patients [36]. The discrepancy could perhaps be due to the difference in samplings and/or relatively lower sample size.

In addition, the promoter region of IL- 6 gene was also evaluated for assessment of the risk contribution to develop $\mathrm{AD}$ or $\mathrm{VaD}$. Varying results have been reported in the literature in the context to polymorphism in the -174 G/C gene of IL-6. Studies conducted in Italy, Japan and Spain [13-15] showed a positive association of the G allele of IL-6 with AD, while other studies observed the C allele having a role in the pathogenesis of $\mathrm{AD}$ [16-18]. In the present study, we did not find any association of the G/C allele in the Alzheimer's group, which is in agreement with the previous reports published form the USA, Italy, Germany, UK, Finland and the Netherlands [19-26]. However, among the $\mathrm{VaD}$ patients, a significant association was found of the $\mathrm{C}$ allele with the diseased state $(\mathrm{p}=$ 0.021 ). To date, there are only limited reports in the literature that have evaluated the role of IL- $6-174$ G/C polymorphism. Among these, one of the studies from the Netherlands [25] did not find any association. Another study from Italy, in which patients with multi-infarct dementia were evaluated, reported an association of the $G$ allele among the diseased population [38]. The present study has shown the association with the Callele. Similar studies which aim to address this issue in patients with $\mathrm{VaD}$ are thus important.

The present study also contributes to etiopathological issues as evident from age-related findings and the OR obtained by multinomial regression analysis. Of the 74 cases of $\mathrm{AD}, 17$ patients ( 11 male and 6 female) were below the age of 60 years. In the younger group of females $(6$ cases), the frequency (66\%) of the ApoE 84 allele was found to be doubled that of females above 60 years (33\%). The most interesting finding in the present study is that among $\varepsilon 4$ allele-positive subjects, it was observed that the absence of GG genotype increased the odds of having $\mathrm{VaD}$ 14.74-fold and AD 13.75-fold.

Besides the genetic study, serum IL- 6 levels were also measured to evaluate their role in the diseased population. No association was found between the IL-6-174 G/C polymorphism and serum levels of IL-6. This observation is supported by previous studies which reported that the level of IL- 6 in blood is not associated with $\mathrm{AD}$ [27, 28]. However, few isolated reports have found such an association $[13,14]$. In our study, the levels of serum IL-6 were relatively higher in both the $\mathrm{AD}$ and $\mathrm{VaD}$ groups as compared to control subjects, but this alteration was not statistically significant.

Although once elevated, the serum IL- 6 level remains at the same level for some time [39]; 1-time measurement of IL- 6 as a biomarker of neurodegenerative disease has its own limitations, offering information only for that time. Additionally, serum levels of any biomarker, including IL-6, does not always reflect the situation within and around the neurons. A longitudinal study with several measurements of IL- 6 may be of some help. Furthermore, IL-6 levels have been reported to increase with age $[40,41]$ and vary with nutrition $[42,43]$. These facts may be taken into consideration when one tries to explain the presence or absence of such an association. In the present study, however, no statistically significant change in serum IL- 6 level was seen with advancement of age.

Nevertheless, the raised serum IL-6 level, in spite of not having any history of vascular or inflammatory episode, merits further exploration. It may be attributed to either the environmental factors or higher frequency of the $\mathrm{G}$ allele among the Indian population [44]. However, the rise was present in the control group of comparable age as well.

In conclusion, we found a statistically significant association of ApoE $\varepsilon 4$ allele among both the diseased groups ( $\mathrm{AD}$ and $\mathrm{VaD}$ ), and the association is stronger in $\mathrm{AD}$ than in VaD. Our study reveals for the first time that the $\mathrm{C}$ allele increased the odds of having VaD 14.74-fold and $\mathrm{AD} 13.75$-fold. In addition, the present study shows an association of the $\mathrm{C}$ allele of IL-6-174 genes with $\mathrm{VaD}$, while in the AD group no such association was observed. That the incidence of the $\varepsilon 4$ allele is almost doubled in younger females (less than 60 years) is also a notable finding in $\mathrm{AD}$ patients.

The current study was carried out in a single tertiary care hospital in Delhi. To strengthen the hypothesis that genetic markers are superior to phenotypic markers for early diagnosis of $\mathrm{AD} / \mathrm{VaD}$, which may be useful for ear-
Mansoori/Tripathi/Alam/Luthra/ Ramakrishnan/Parveen/Mukhopadhyay 
ly detection of the disease-prone subjects in the prevalent area, such a study should be conducted with a large sample size with a multicenter and multiethnic approach involving both hospital-based and community-based populations. The role of serum IL- 6 and polymorphism of its genes in $\mathrm{AD}$ and $\mathrm{VaD}$ patients could be further elucidated by designing studies which evaluate the role of other inflammatory cytokine genes which have influence on the serum IL-6 level.

\section{Acknowledgements}

The authors acknowledge the Indian Council of Medical Research (ICMR), New Delhi, for providing financial assistance for this study. We also acknowledge the input from Prof. R.M. Pandey, Department of Biostatistics, for helping with statistical evaluation.

\section{References}

-1 Shaji S, Promodu K, Abraham T, Roy KJ, Verghese A: An epidemiological study of dementia in a rural community in Kerala, India. Br J Psychiatry 1996;168:745-749.

-2 Zhang MY, Katzman R, Salmon D, et al: The prevalence of dementia and Alzheimer's disease in Shanghai, China: impact of age, gender, and education. Ann Neurol 1990;27: 428-437.

3 Kalaria RN, Maestre GE, Arizaga R, Friedland RP, Galasko D, Hall K, Luchsinger JA, Ogunniyi A, Perry EK, Potocnik F, Prince M, Stewart R, Wimo A, Zhang ZX, Antuono P, World Federation of Neurology Dementia Research Group: Alzheimer's disease and vascular dementia in developing countries: prevalence, management, and risk factors. Lancet Neurol 2008;7:812-826.

4 Thakur MK. Alzheimer's disease: a challenge in new millennium. Curr Sci 2000;79: 29-36.

5 Saunders AM, Strittmatter WJ, Schmechel D, et al: Association of apolipoprotein E allele epsilon 4 with late-onset familial and sporadic Alzheimer's disease. Neurology 1993;43:1467-1472.

6 Papassotiropoulos A, Streffer JR, Hock C, Nitsch RM: Genetics of Alzheimer's disease. Schweiz Arch Neurol Psychiatr 2001;152: 278-287.

7 Sando SB, Melquist S, Cannon A, Hutton ML, Sletvold O, Saltvedt I, White LR, Lydersen S, Aasly JO: APOE $\varepsilon 4$ lowers age at onset and is a high risk factor for Alzheimer's disease; a case control study from central Norway. BMC Neurology 2008,8:9.

8 Frank A, Díez-Tejedor E, Bullido MJ, Valdivieso F, Barreiro P: APOE genotype in cerebrovascular disease and vascular dementia. J Neurol Sci 2002;203-204:173-176.
-9 Orsitto G, Seripa D, Panza F, Franceschi M, Cascavilla L, Placentino G, Matera MG, Paris F, Capurso C, Solfrizzi V, Dallapiccola B, Pilotto A: Apolipoprotein E genotypes in hospitalized elderly patients with vascular dementia. Dement Geriatr Cogn Disord 2007;23:327-333.

10 Chapman J, Wang N, Treves TA, Korczyn AD, Bornstein NM: ACE, MTHFR, factor V Leiden, and APOE polymorphisms in patients with vascular and Alzheimer's dementia. Stroke 1998;29:1401-1404.

11 Katzman R, Zhang MY, Chen PJ, Gu N, Jiang S, Saitoh T, Chen X, Klauber M, Thomas RG, Liu WT, Yu ES: Effects of apolipoprotein E on dementia and aging in the Shanghai Survey of Dementia. Neurology 1997;49:779785.

12 Vitek MP, Brown CM, Colton CA: APOE genotype-specific differences in the innate immune response. Neurobiol Aging 2009; 30:1350-1360.

13 Shibata N, Ohnuma T, Takahashi T, Baba H, Ishizuka T, Ohtsuka M, Ueki A, Nagao M, Arai H: Effect of IL-6 polymorphism on risk of Alzheimer disease: genotype-phenotype association study in Japanese cases. Am J Med Genet 2002;114:436-439.

14 Mateo I, Infante J, Rodríguez E, Berciano J, Combarros O, Llorca J: Interaction between dopamine beta-hydroxylase and interleukin genes increases Alzheimer's disease risk. J Neurol Neurosurg Psychiatry 2006;77:278279.

15 Pola R, Flex A, Gaetani E, Lago AD, Gerardino L, Pola P, Bernabei R: The -174 G/C polymorphism of the interleukin- 6 gene promoter is associated with Alzheimer's disease in an Italian population [corrected]. Neuroreport 2002;13:1645-1647.

16 Licastro F, Grimaldi LM, Bonafe M, Martina C, Olivieri F, Cavallone L, Giovanietti S, Masliah E, Franceschi C: Interleukin-6 gene alleles affect the risk of Alzheimer's disease and levels of the cytokine in blood and brain. Neurobiol Aging 2003;24:921-926.
17 Arosio B, Trabattoni D, Galimberti L, Bucciarelli P, Fasano F, Calabresi C, Cazzullo CL, Vergani C, Annoni G, Clerici M: Interleukin-10 and interleukin- 6 gene polymorphisms as risk factors for Alzheimer's disease. Neurobiol Aging 2004;25:1009-1015.

18 Licastro F, Porcellini E, Caruso C, Lio D, Corder EH: Genetic risk profiles for Alzheimer's disease: integration of APOE genotype and variants that up-regulate inflammation. Neurobiol Aging 2007;28:1637-1643.

19 Li H, Wetten S, Li L, St Jean PL, Upmanyu R, Surh L, Hosford D, Barnes MR, Briley JD, Borrie M, Coletta N, Delisle R, Dhalla D, Ehm MG, Feldman HH, Fornazzari L, Gauthier S, Goodgame N, Guzman D, Hammond S, Hollingworth P, Hsiung GY, Johnson J, Kelly DD, Keren R, Kertesz A, King KS, Lovestone S, Loy-English I, Matthews PM, Owen MJ, Plumpton M, Pryse-Phillips W, Prinjha RK, Richardson JC, Saunders A, Slater AJ, St George-Hyslop PH, Stinnett SW, Swartz JE, Taylor RL, Wherrett J, Williams J, Yarnall DP, Gibson RA, Irizarry MC, Middleton LT, Roses AD: Candidate singlenucleotide polymorphisms from a genome wide association study of Alzheimer disease. Arch Neurol 2008;65:45-53.

20 Ravaglia G, Paola F, Maioli F, Martelli M, Montesi F, Bastagli L, Bianchin M, Chiappelli M, Tumini E, Bolondi L, Licastro F: Interleukin-1beta and interleukin- 6 gene polymorphisms as risk factors for $\mathrm{AD}$ : a prospective study. Exp Gerontol 2006;41:8592.

21 Depboylu C, Lohmuller F, Gocke P, Du Y, Zimmer R, Gasser T, Klockgether T, Dodel $\mathrm{RC}$ : An interleukin- 6 promoter variant is not associated with an increased risk for $\mathrm{Alz}$ heimer's disease. Dement Geriatr Cogn Disord 2004;17:170-173. 
22 Bagli M, Papassotiropoulos A, Knapp M, Jessen F, Luise Rao M, Maier W, Heun R: Association between an interleukin- 6 promoter and $3^{\prime}$ flanking region haplotype and reduced Alzheimer's disease risk in a German population. Neurosci Lett 2000;283:109112.

23 Zhang Y, Hayes A, Pritchard A, Thaker U, Haque MS, Lemmon H, Harris J, Cumming A, Lambert JC, Chartier-Harlin MC, St Clair D, Iwatsubo T, Mann DM, Lendon CL: Interleukin-6 promoter polymorphism: risk and pathology of Alzheimer's disease. Neurosci Lett 2004;362:99-102.

- 24 Koivisto AM, Helisalmi S, Pihlajamaki J, Moilanen L, Kuusisto J, Laakso M, Hiltunen M, Keijo K, Hanninen T, Helkala EL, Kervinen $\mathrm{K}$, Kesaniemi YA, Soininen H: Interleukin-6 promoter polymorphism and lateonset Alzheimer's disease in the Finnish population. J Neurogenet 2005;19:155-161.

-25 Van Oijen M, Arp PP, de Jong FJ, Hofman A, Koudstaal PJ, Uitterlinden AG, Breteler MM: Polymorphisms in the interleukin 6 and transforming growth factor betal gene and risk of dementia. The Rotterdam Study. Neurosci Lett 2006;402:113-117.

-26 Capurso C, Solfrizzi V, Colacicco AM, D’Introno A, Frisardi V, Imbimbo BP, Lorusso M, Vendemiale G, Denitto M, Santamato A, Seripa D, Pilotto A, Fiore P, Capurso A, Panza F: Interleukin 6-174 G/C promoter and variable number of tandem repeats (VNTR) gene polymorphisms in sporadic Alzheimer's disease. Prog Neuropsychopharmacol Biol Psychiatry 2010;34:177-182.

-27 Angelis P, Scharf S, Mander A, Vajda F, Christophidis N: Serum interleukin- 6 and interleukin-6 soluble receptor in Alzheimer's disease. Neurosci Lett 1998;244:106108.
28 Lanzrein AS, Johnston CM, Perry VH, Jobst KA, King EM, Smith AD: Longitudinal study of inflammatory factors in serum, cerebrospinal fluid, and brain tissue in Alzheimer disease: interleukin-1beta, interleukin-6, interleukin-1 receptor antagonist, tumor necrosis factor-alpha, the soluble tumor necrosis factor receptors I and II, and alpha1-antichymotrypsin. Alzheimer Dis Assoc Disord 1998;12:215-227.

29 Valente C, Maione P, Lippi A, et al: Validation of the Mini-Mental State Examination (MMSE) as a screening instrument for dementia in an Italian population. Giorn Gerontol 1992;40:161-5.

30 Miller SA, Dykes DD, Polesky HF: A simple salting out procedure for extracting DNA from human nucleated cells. Nucleic Acid Res 1988; 16:1215.

31 Wenham PR, Price WH, Blundell G: Apolipoprotein E genotyping by one-stage PCR. Lancet 1991;337:1158-1159.

32 Fishman D, Faulds G, Jeffery R, MohamedAli V, Yudkin JS, Humphries S, Woo P: The effect of novel polymorphisms in the interleukin-6 (IL-6) gene on IL-6 transcription and plasma IL-6 levels, and an association with systemic-onset juvenile chronic arthritis. J Clin Invest 1998;102:1369-1376.

33 Janka Z, Juhász A, Rimanóczy A A, Boda K, Márki-Zay J, Kálmán J: Codon 311 (Cys -> Ser) polymorphism of paraoxonase- 2 gene is associated with apolipoprotein E4 allele in both Alzheimer's and vascular dementias. Mol Psychiatry 2002;7:110-112.

34 Raygani AV, Zahrai M, Raygani AV, Doosti M, Javadi E, Rezaei M, Pourmotabbed T: Association between apolipoprotein E polymorphism and Alzheimer disease in Tehran, Iran. Neurosci Lett 2005;375:1-6.

35 Pandey P, Pradhan S, Mittal B: Presenilin gene predisposes to late-onset degenerative but not vascular dementia: a comparative study of PS1 and ApoE genes in a North Indian Cohort. Dement Geriatr Cogn Disord 2007;24:151-161.

$>36$ Luthra K, Tripathi M, Grover R, Dwivedi M, Kumar A, Dey AB: Apolipoprotein E gene polymorphism in Indian patients with Alzheimer's disease and vascular dementia. Dement Geriatr Cogn Disord 2004;17:132-135.
37 Pirttilä T, Lehtimäki T, Rinne J, Mattila K, Frey H, Nikkari T: The frequency of apolipoprotein E4 allele is not increased in patients with probable vascular dementia. Acta Neurol Scand 1996;93:352-354.

38 Pola R, Gaetani E, Flex A, Aloi F, Papaleo P, Gerardino L, De Martini D, Flore R, Pola P, Bernabei R: -174 G/C interleukin-6 gene polymorphism and increased risk of multiinfarct dementia: a case-control study. Exp Gerontol 2002;37:949-955.

39 Rao KM, Pieper CS, Currie MS, Cohen HJ: Variability of plasma IL- 6 and cross linked fibrin dimers over time in community dwelling elderly subjects. Am J Clin Pathol 1994; 102:802-805.

40 Ershler WB, Keller ET: Age-associated increased interleukin- 6 gene expression, latelife diseases, and frailty. Annu Rev Med 2000;51:245-270.

41 Krabbe KS, Pedersen M, Bruunsgaard H: Inflammatory mediators in the elderly. Exp Gerontol 2004;39:687-699.

42 Esposito K, Marfella R, Ciotola M, Di Palo C, Giugliano F, Giugliano G, D’Armiento M, D'Andrea F, Giugliano D: Effect of a Mediterranean-style diet on endothelial dysfunction and markers of vascular inflammation in the metabolic syndrome: a randomized trial. JAMA 2004;292:1440-1446.

43 Kopp HP, Kopp CW, Festa A, Kryzanowska K, Kriwanek S, Minar E, Roka R, Schernthaner G: Impact of weight loss on inflammatory proteins and their association with the insulin resistance syndrome in morbidly obese patients. Arterioscler Thomb Vasc Biol 2003;23:1042-1047.

-44 Kaur G, Rapthap CC, Kumar N, Kumar S, Neolia S, Mehra NK: Frequency distribution of cytokine gene polymorphisms in the healthy North Indian population. Tissue Antigens 2007;69:113-120.
Mansoori/Tripathi/Alam/Luthra/ Ramakrishnan/Parveen/Mukhopadhyay 